\title{
TEMPORAL AND SPATIAL CHANGES IN THE CONCENTRATIONS OF RADIOCAESIUM AND RADIOSTRONTIUM IN THE VLTAVA RIVER BASIN AFFECTED BY THE OPERATION OF THE NUCLEAR POWER PLANT AT TEMELÍN
}

\author{
EDUARD HANSLÍK*, DIANA MAREŠOVÁ, and EVA JURANOVÁ
}

T. G. Masaryk Water Research Institute, Public Research Institution, Podbabská 30, 16000 Prague 6, Czech Republic

*Corresponding author: eduard_hanslik@vuv.cz

\begin{abstract}
Concentrations of radiocaesium and radiostrontium were assessed in surface water, sediment, fish and aquatic flora affected and not affected by waste water discharges from the Temelín Nuclear Power Plant. The assessment included residual contamination originating from nuclear weapon tests in the atmosphere over the last century and the accident at Chernobyl in 1986. Results of long-term monitoring (since 1990) were used to derive effective ecological half-lives of these radionuclides in the hydrosphere. Possible effect of waste water discharged from Temelín power plant on the concentrations of radiocaesium and radiostrontium in the Vltava River was assessed by using data recorded in the period 2001-2010.
\end{abstract}

Keywords: nuclear power plants, radiocaesium, radiostrontium, hydrosphere

\section{Introduction}

This paper focuses on an analysis of the results of long-term monitoring and assessment of concentrations of radionuclides in the hydrosphere in the vicinity of the Nuclear Power Plant at Temelín.

This nuclear power plant discharges waste water that contains radioactive substances, of which tritium is the most important. The waste water also includes other radionuclides, which originate mainly from local surface water used to cool the reactor in the plant along with minor quantities that originate from the standard operation of the plant. The radionuclides that could have originated from the power plant include mainly tritium, as the amounts of fission products, such as radiocaesium and radiostrontium, released during routine operation are very low. Average annual amount of ${ }^{137} \mathrm{Cs}$ and ${ }^{90} \mathrm{Sr}$ released from the Temelín plant in the period 2002-2010 was $0.057 \mathrm{GBq}^{-1}$ and $0.001 \mathrm{MBq}^{-1}$, respectively (Hanslík 2000-2011). The radionuclides of artificial origin were detected in the environment in the vicinity of the Temelín plant before it started operating in 2001 and attributed to radionuclide contamination of the environment that resulted from tests of nuclear weapons in the atmosphere in the fifties and sixties in the 20th century and the accident at Chernobyl in 1986.

Caesium 134 and $137\left({ }^{134} \mathrm{Cs},{ }^{137} \mathrm{Cs}\right)$ and strontium $90\left({ }^{90} \mathrm{Sr}\right)$ are radioecologically important radionuclides, which remain in the environment for a long time because they have long half-lives $(2.1,30.2$ and $28.8 \mathrm{y})$. In previous research projects it was mainly the concentration of ${ }^{137} \mathrm{Cs}$ that was measured because the concentrations of this radionuclide can be determined using gammaspectrometric analysis, which requires special equipment, but its determination is less time consuming than the radiochemical determination of beta emitters such as ${ }^{90} \mathrm{Sr}$. This accounts for the little data and knowledge of the concentrations of ${ }^{90} \mathrm{Sr}$ compared to other radionuclides in the Czech Republic and elsewhere (Outola et al. 2009).

Construction and operation of the Temelín plant initiated the implementation of a number of projects, which focused on the possible effects of this power plant on the environment. This resulted in the collection of data, which currently spans a period of 20 years. The first two projects (Hanslík 1995; Hanslík 1998) were sponsored by the Czech Ministry of the Environment and their main objectives were to determine the pre-operational environmental conditions (a reference level) in terms of concentrations of radioactive and non-radioactive substances present in the environment, particularly in the hydrosphere, and predict possible effects of the future operation of the Temelín power plant. This monitoring and research continued during the period 1999-2010 within the framework of a project sponsored by the Czech Power Company (Hanslík 2000-2011) and one on the Research and protection of the hydrosphere - research on the relationships and processes in the water component of the environment, which focused on effects of human pressure, the sustainable use and protection of the hydrosphere and legislative tools (MZP 0002071101 sponsored by the Czech Ministry of the Environment). The main objectives of these projects were to assess the effects of the waste water discharged from the Temelín power plant on the concentration of tritium, radiocaesium and radiostrontium in the hydrosphere, compare these effects with the residual contamination from the tests of nuclear weapons in the atmosphere and the Cher- 


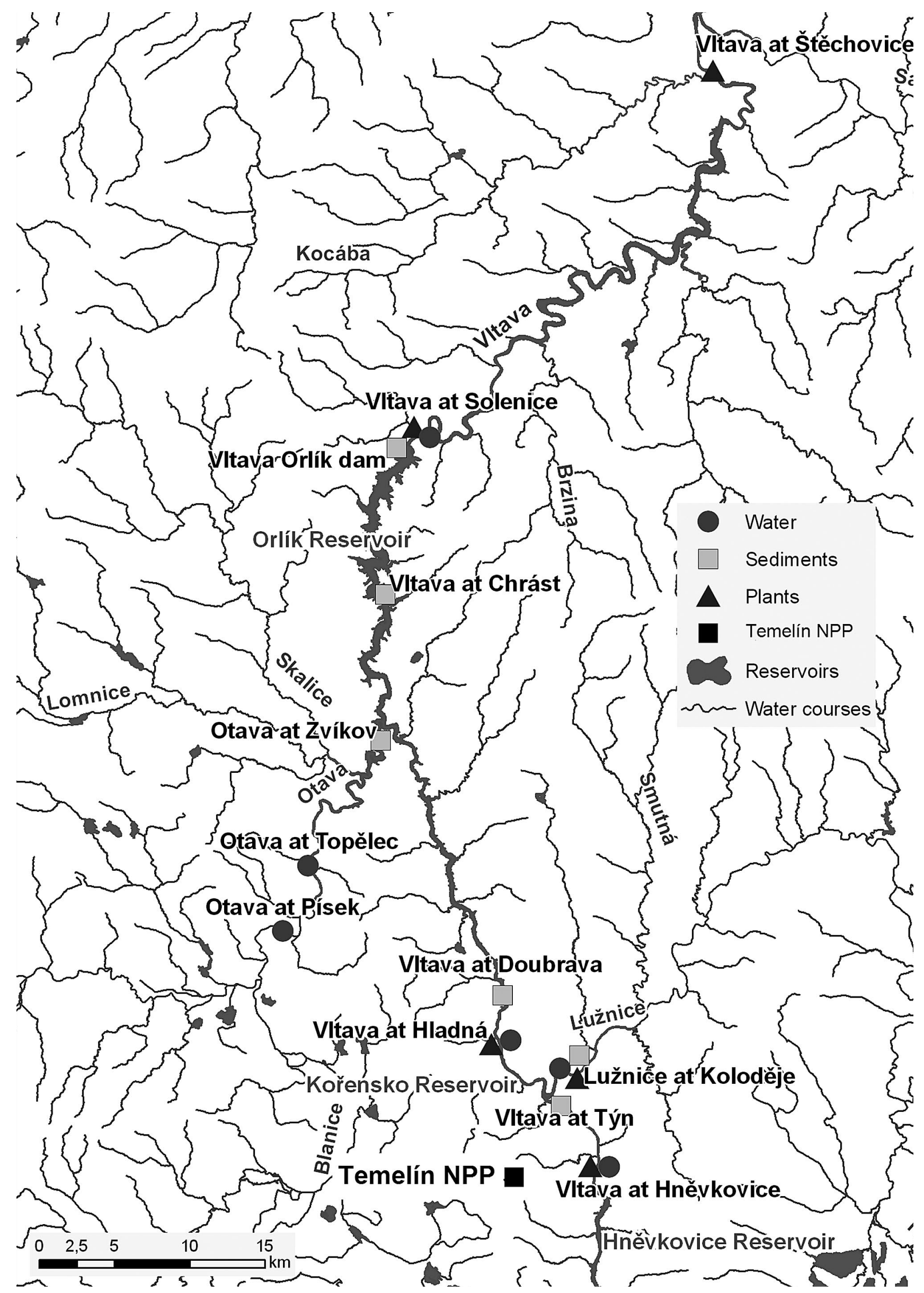

Fig. 1 Map of sampling sites. 
nobyl accident in the last century and evaluate the longterm spatial and temporal trends in the concentrations of these radionuclides monitored at sites not affected and affected by the outflow of waste water from the Temelín power plant. This paper reviews and summarizes the main results of these projects in terms of radiocaesium and radiostrontium. The results on tritium were previously published by Ivanovová and Hanslík (2010).

\section{Methods}

The changes in the concentrations of radiocaesium and radiostrontium were monitored in the tributaries of the Orlík Reservoir, the Vltava, Lužnice and Otava Rivers, which are located upstream from the waste water outflow from the Temelín power plant and represent the reference conditions ("reference sampling sites"), and in the Vltava River downstream from the outflow of waste water from the power plant ("affected sampling sites"). The monitoring involved determining concentrations in surface water, bottom sediments, fish and water plants (Fig. 1). The monitoring of the concentrations in the surface water and sediments was started in 1990, fish during the period 1986-1990, in 1994 and annually since 1998, and aquatic plants in the period 1996-2010.

The collection and processing of the samples follow those specified in ČSN EN 25667-1 (1994) and 2 (1994) Standards and ČSN EN ISO 5667-3 (1996), 4 (1994) and 6 (1994). Quality control practices of the T.G.M WRI Radioecological Laboratory were followed as specified in the Standard ČSN EN ISO/IEC 17025 (2001; 2005). This laboratory is responsible for the national and international proficiency testing.

Four separate large samples of water (50 l) were collected each year. These samples were immediately stabilized with nitric acid to $\mathrm{pH} 1$ and then, after transportation to the laboratory, dried by vaporization. The vaporized samples were ignited $\left(350^{\circ} \mathrm{C}\right)$ and enclosed into Petri dishes. The radionuclides concentrations in water were determined in total solids (both in dissolved and suspended solids). Samples of water (1 l l) for determining total suspended solids (TSS) were collected with the same frequency. Samples of sediment were collected by a diver from the top layer $(0-10 \mathrm{~cm})$ of the sediment at the bottom at six sites in tributaries of the Vltava River and Orlík Reservoir. The frequency of sampling was once a year. Granularity of the samples was generally less than $2 \mathrm{~mm}$. For the analysis, the samples were dried at $105^{\circ} \mathrm{C}$ and hermetically sealed in measuring containers. Samples of fish and water plants were also collected annually. These samples were dried at $105^{\circ} \mathrm{C}$ and hermetically sealed in measuring containers.

The ${ }^{134} \mathrm{Cs}$ and ${ }^{137} \mathrm{Cs}$ concentrations were analyzed following the Standard ČSN ISO 10703 procedure (1999; 2008) using gamma-spectrometry. A Canberra device was used. The measurement duration was set to the re- quested minimum detectable activity (MDA) of ${ }^{137} \mathrm{Cs}$ and level of significance of $\alpha=\beta=0.05$. The MDA of ${ }^{137} \mathrm{Cs}$ in water counted over a period of 2 days was $0.5 \mathrm{mBq} \mathrm{1}^{-1}$. In the sediments, the MDA of ${ }^{137} \mathrm{Cs}$ counted over a period of $8 \mathrm{~h}$ was approximately $0.5 \mathrm{~Bq} \mathrm{~kg}^{-1}$. The results recorded for ${ }^{137} \mathrm{Cs}$ activity in fish (dried samples) were converted to activity in terms of wet weight. The MDA of ${ }^{137} \mathrm{Cs}$ in fish (wet weight) counted over a period of 2 days was $0.1 \mathrm{~Bq} \mathrm{~kg}^{-1} .{ }^{90} \mathrm{Sr}$ in water was determined by using a standard method after radiochemical separation (Hanslík 1993). Its activity was detected in the residue left after ignition and detected using yttrium 90 after radiochemical separation. Value of MDA of ${ }^{90} \mathrm{Sr}$ was $3 \mathrm{lmBq} \mathrm{l}^{-1}$. These methods were verified and recommended by the International Atomic Energy Agency (IAEA 1996) in Vienna as part of the technical assistance agreement with the Ministry of the Environment of the CR and the State Office for Nuclear Safety.

The data on the concentrations of radionuclides in water, sediments and biomass were assessed using several mathematical methods, which are briefly described below.

The effective ecological half-lives were determined using the decrease in the activity of a radionuclide and the equation published by Smith and Beresford (2005):

$$
T_{e f f}=\frac{\ln 2}{\lambda_{e f f}}
$$

where $T_{e f f}$ is effective ecological half-life (y) and $\lambda_{e f f}$ is effective ecological decay constant of the radionuclide activity concentration $\left(\mathrm{y}^{-1}\right)$.

Ecological half-lives were calculated by using the equation proposed by Smith and Beresford (2005):

$$
\frac{1}{T_{\text {ecol }}}=\frac{1}{T_{\text {eff }}}-\frac{1}{T_{P}}
$$

where $T_{\text {ecol }}$ is ecological half-life $(\mathrm{y})$ and $T_{p}$ is physical half-life (y).

For trend analyses a kinetic equation of the first order of the following form was used (an example for ${ }^{137} \mathrm{Cs}$ ):

$$
\ln \left(\mathrm{c}_{137 \mathrm{Cs}, j}\right)=-\lambda_{\text {eff }} \cdot t+q
$$

where $c_{137 \mathrm{Cs}, \mathrm{j}}$ is annual average concentration of ${ }^{137} \mathrm{Cs}$ in surface water $\left(\mathrm{Bq} \mathrm{m}^{-3}\right)$ in year $j, \lambda_{\text {eff }}$ is effective rate of decline in concentration of ${ }^{137} \mathrm{Cs}\left(\mathrm{y}^{-1}\right)$, involving the physical decay constant $\left(\lambda_{p}\right)$ and ecological rate of decrease $\left(\lambda_{\text {ecol }}\right), \lambda_{\text {eff }}=\lambda_{p}+\lambda_{\text {ecol }}\left(\mathrm{y}^{-1}\right), \mathrm{t}$ is incidence of the monitoring measured in years, and $q$ is natural logarithm of activity at the beginning of the observation.

The ecological and effective ecological half-lives were calculated for a confidence level of $68 \%$ using the ERA 3.0 program.

The annual depositions of suspended solids in a reservoir were calculated using the following equation: 
$D_{\mathrm{S}, \mathrm{j}}=\left(\sum_{t=1}^{n} c_{S, j, t} \cdot Q_{j, t}+c_{S, j, i a} \cdot Q_{j, i a}-c_{S, j, o} \cdot Q_{j, o}\right) \cdot t \cdot 10^{-3}$

where $D_{S, j}$ is deposition of suspended solids in a reservoir in individual years $(j)\left(\mathrm{t}^{-1}\right), c_{S, j, t}$ is mean annual concentration of suspended solids $(j)$ in individual tributaries $(t)\left(\mathrm{kg} \mathrm{m}^{-3}\right), c_{S, j, i a}$ is mean annual concentration of suspended solids $(j)$ in the inflow from inter-basin area (ia) $\left(\mathrm{kg} \mathrm{m}^{-3}\right), c_{S, j, o}$ is mean annual concentration of suspended solids $(j)$ in the outflow from a reservoir $\left(\mathrm{kg} \mathrm{m}^{-3}\right)$, $Q_{j, t}$ is mean annual inflow $(j)$ from individual tributaries $(t)\left(\mathrm{m}^{3} \mathrm{~s}^{-1}\right), Q_{j, i a}$ is mean annual inflow $(j)$ from the inter-basin area $\left(\mathrm{m}^{3} \mathrm{~s}^{-1}\right)$, and $Q_{j, o}$ is mean annual outflow (j) from a reservoir $\left(\mathrm{m}^{3} \mathrm{~s}^{-1}\right)$.

The deposition of suspended solids was also calculated for individual years using the following formula and expressed in percentages:

$D_{S, j}=\frac{\sum_{i=1}^{n} c_{S, j, t} \cdot Q_{j, t}+c_{S, j, i a} \cdot Q_{j, i a}-c_{S, j, o} \cdot Q_{j, o}}{\sum_{t=1}^{n} c_{S, j, t} \cdot Q_{j, t}+c_{S, j, i a} \cdot Q_{j, i a}} \cdot 100$

where $D_{S, j}$ is the deposition of suspended solids in a reservoir in individual years $(j)(\%)$.

Similarly, based on the results of monitoring the ${ }^{137} \mathrm{Cs}$ activity in all substances in water (dissolved as well as undissolved solids), the deposition of ${ }^{137} \mathrm{Cs}$ can be determined using the formula:

$$
\begin{aligned}
& D_{A, 137 C s, j}=\left(\sum_{t=1}^{n} c_{137 C s, j, t} \cdot Q_{j, t}+c_{137 C s, j, i a} \cdot Q_{j, i a}-\right. \\
& \left.c_{137 C s, j, o} \cdot Q_{j, o}\right) \cdot t \cdot 10^{-9}
\end{aligned}
$$

where $D_{A, 137 C S, j}$ is the deposition of ${ }^{137} \mathrm{Cs}$ in individual years $(j)\left(\mathrm{GBq}^{-1}\right), \mathrm{c}_{137 \mathrm{Cs}, \mathrm{j}, \mathrm{t}}$ is mean annual activity of ${ }^{137} \mathrm{Cs}(j)$ in individual tributaries $(t)$ of a reservoir $\left(\mathrm{Bq} \mathrm{m}^{-3}\right), \mathrm{c}_{137 \mathrm{Cs}, j, i a}$ is mean annual activity of ${ }^{137} \mathrm{Cs}(j)$ the inflow from inter-basin area $(\mathrm{ia})\left(\mathrm{Bq} \mathrm{m}^{-3}\right), c_{137 c s, j, o}$ is mean annual activity of ${ }^{137} \mathrm{Cs}(j)$ in the outflow from a reservoir in $\mathrm{Bq} \mathrm{m}^{-3}$.
Concentration factors $(C F)$ for fish samples were calculated using the equation recommended by Smith and Beresford (2005):

$$
C F=\frac{\bar{a}_{137 C s}}{\bar{c}_{137 C s}}
$$

where is annual weighted average concentration of ${ }^{137} \mathrm{Cs}$ in fish (wet weight) $\left(\mathrm{Bq} \mathrm{kg}^{-1}\right)$, and is annual average concentration of ${ }^{137} \mathrm{Cs}$ in water in tributaries of Orlík Reser$\operatorname{voir}\left(\mathrm{Bq}^{-1}\right)$.

The concentration factors were calculated for a confidence level of $68 \%$ as standard deviations.

\section{Results and discussion}

\section{Concentrations of ${ }^{137} \mathrm{Cs}$ and ${ }^{90} \mathrm{Sr}$ in water}

Temporal changes in the concentrations of ${ }^{137} \mathrm{Cs}$ in water samples collected from Orlík Reservoir and its tributaries in two periods, 1990-1994 and 1995-2010, were determined. The effective ecological half-lives $\left(T_{\text {eff }}\right)$ in water in individual tributaries and the outflow from Orlík Reservoir (Table 1) were in the range of 1.1-2.2 y for the period 1990-1994 and 6.2-10.9 y for the period 1995-2010. The ecological half-lives $\left(T_{\text {ecol }}\right)$ were in the range 1.2-2.4 y for the period 1990-1994 and 5.1-8.0 y for the period 1995-2010. The results of these studies showed that the decrease in the concentrations of ${ }^{137} \mathrm{Cs}$, which was observed before the power plant began operating, continued also during the subsequent period. An example is shown in Fig. 2 for the Vltava River at Hněvkovice (a reference sampling site, source of technological water) and Solenice (downstream from the Temelín waste water outflow). In 2010, the average activity of ${ }^{137} \mathrm{Cs}$ at Hněvkovice was $0.5 \mathrm{mBq} \mathrm{l}^{-1}$ and at Solenice $0.3 \mathrm{mBq}^{-1}$.

The results of these studies carried out in the vicinity of the Temelín plant are in agreement with those of similar studies on changes in water contamination after the Chernobyl accident. For example, Zibold et al. (2001) recorded a fast decrease in the concentration of ${ }^{137} \mathrm{Cs}$ in the period 1986-1988 and a second slower decrease

Table 1 The evaluated effective ecological half-lives and ecological half-lives of ${ }^{137} \mathrm{Cs}$ in water in the tributaries and outflow of the Orlík Reservoir in the periods 1990-1994 and 1995-2010.

\begin{tabular}{|l|c|c|c|c|}
\hline \multicolumn{1}{|c|}{ Period } & \multicolumn{2}{|c|}{$1990-1994$} & $1995-2010$ \\
\hline Tributaries of Orlík Reservoir & $\boldsymbol{T}_{\text {eff }}(\mathrm{y})$ & $\boldsymbol{T}_{\text {ecol }}(\mathrm{y})$ & $\boldsymbol{T}_{\text {eff }}(\mathrm{y})$ & \multicolumn{1}{|c|}{$\boldsymbol{T}_{\text {ecol }}(\mathrm{y})$} \\
\hline Vltava River at Hněvkovice & $1.5 \pm 0.9$ & $1.6 \pm 1.0$ & $6.7 \pm 1.8$ \\
\hline Lužnice River at Koloděje & $2.2 \pm 1.6$ & $2.4 \pm 2.0$ & $10.9 \pm 4.9$ & $17.0 \pm 12.0$ \\
\hline Otava River at Topělec & $1.5 \pm 1.1$ & $1.5 \pm 1.3$ & $6.3 \pm 2.1$ & $8.0 \pm 3.3$ \\
\hline The outflow from Orlík Reservoir (the Vltava River at Solenice) & $1.5 \pm 0.6$ & $1.5 \pm 0.7$ & $6.2 \pm 1.7$ \\
\hline
\end{tabular}




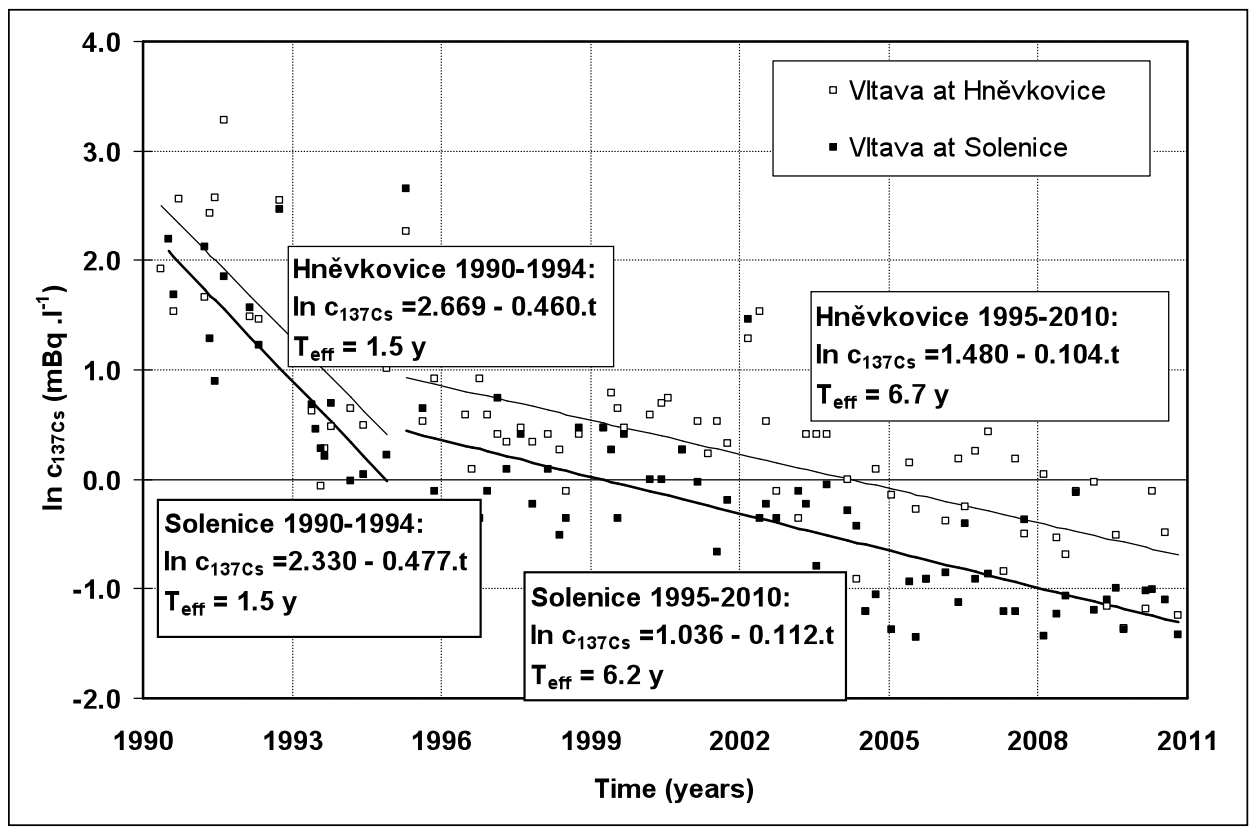

Fig. 2 Temporal changes of ${ }^{137} \mathrm{Cs}$ concentration $\left(\mathrm{c}_{137 \mathrm{Cs}}\right.$ ) in the Vltava River at Hněvkovice (source of technological water) and the Vltava River at Solenice (downstream from the Temelín waste water outflow) in the periods 1990-1994 and 1995-2010.

in 1989-2000. Similarly, the rate of decline in the concentration of ${ }^{137} \mathrm{Cs}$ in the Pripyat River has decreased in recent years (Smith and Beresford 2005). The effective ecological half-lives of 1.2 years (dissolved phase) and $1.7 \mathrm{y}$ (particulate phase) in the period 1987-1991 increased to $3.4 \mathrm{y}$ (dissolved phase) and $11.2 \mathrm{y}$ (particulate phase) in the period 1995-1998. This increase in $T_{\text {eff }}$ was also recorded in Belarus, Ukraine and Finland (Smith and Beresford 2005).

Temporal changes in the concentrations of ${ }^{90} \mathrm{Sr}$ in water samples collected from Orlík Reservoir and its tributaries were recorded for the period 1993-2010. The effective ecological half-lives $\left(T_{e f f}\right)$ in the water from individual tributaries and outflow from Orlík Reservoir (Table 2) were in the range 7.9-12.8 y and the ecological half-lives $\left(T_{\text {ecol }}\right)$ in the range 10.8-22.9 y. An example is shown in Fig. 3 for the Vltava River at Hněvkovice and Solenice. In 2010, the average activity of ${ }^{90} \mathrm{Sr}$ at Hněvkovice was $2.9 \mathrm{mBq}^{-1}$ and at Solenice $2.3 \mathrm{mBq}^{-1}$. The anthropogenic radionuclides ${ }^{137} \mathrm{Cs}$ and ${ }^{90} \mathrm{Sr}$ in the hydrosphere downstream from where waste water is discharged from the Temelín power plant originated mainly

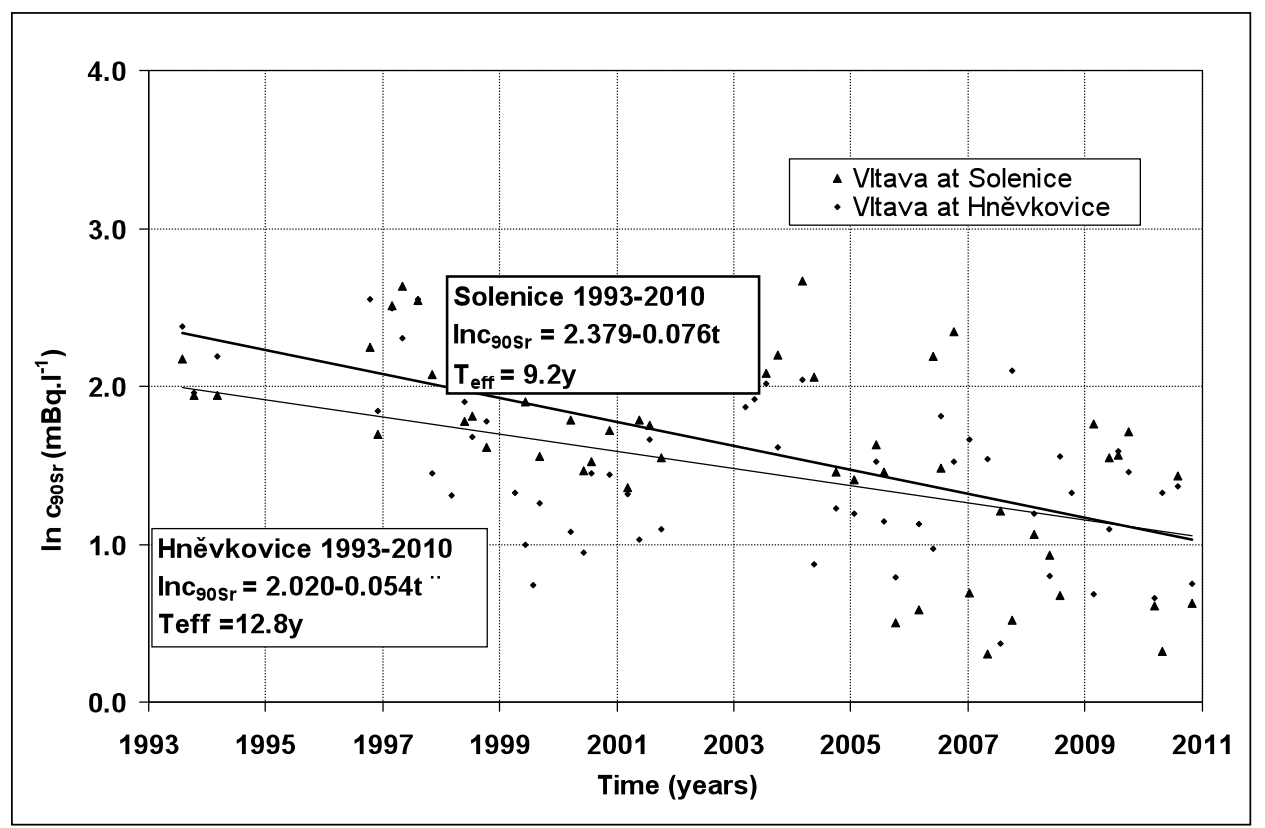

Fig. 3 Temporal changes of ${ }^{90} \mathrm{Sr}$ concentration $\left(\left(_{905 r}\right)\right.$ in the Vltava River at Hněvkovice and the Vltava River at Solenice in the period $1993-2010$. 
Table 2 The evaluated effective ecological half-lives and ecological half-lives of ${ }^{90} \mathrm{~S} r$ in water in the tributaries and outflow of the Orlík Reservoir in the period 1993-2010.

\begin{tabular}{|l|c|c|}
\hline \multicolumn{1}{|c|}{ Period } & \multicolumn{2}{|c|}{$1995-2010$} \\
\hline Tributaries of Orlík Reservoir & $T_{\text {eff }}(\mathbf{y})$ & $12.8 \pm 5.9$ \\
\hline Vltava River at Hněvkovice & $7.9 \pm 2.7$ & $22.9 \pm 10.6$ \\
\hline Lužnice River at Koloděje & $9.4 \pm 3.3$ & $10.8 \pm 3.7$ \\
\hline Otava River at Topělec & $9.2 \pm 3.5$ & $14.0 \pm 4.9$ \\
\hline The outflow from Orlík Reservoir (the Vltava River at Solenice) & $13.5 \pm 5.1$ \\
\hline
\end{tabular}

from the residual contamination from tests of nuclear weapons in the atmosphere and the Chernobyl accident. The activity of these radionuclides is decreasing and currently the concentrations in surface water are near their detection limits.

Over the period of this study the concentrations of ${ }^{137} \mathrm{Cs}$ and ${ }^{90} \mathrm{Sr}$ in the tributaries of Orlík Reservoir were similar to that recorded in other European countries that were affected by radioactive fallout from the Chernobyl accident. For example, in Finland and the concentrations of ${ }^{137} \mathrm{Cs}$ recorded in Lago Maggiore and its tributaries in Italy (Putarskaya et al. 2009). The difference in the decline in the concentration of ${ }^{137} \mathrm{Cs}$ and ${ }^{90} \mathrm{Sr}$ is reported for a number of European rivers. Concentrations of ${ }^{137} \mathrm{Cs}$ in the global fallout from the Chernobyl accident after the tests of nuclear weapons in the atmosphere greatly exceeded those of ${ }^{90} \mathrm{Sr}$. The activities of both radionuclides rapidly declined in the initial period and this trend continued for ${ }^{137} \mathrm{Cs}$ but the rate of decline in the activity of ${ }^{90} \mathrm{Sr}$ has decreased. This is reflected in lengthening of its effective ecological half-life (Smith et al. 2000a). However, the activities of these radionu- clides continued to decrease at all the river sites we studied after the Temelín power plant became operational (since 2001).

\section{Concentrations of radiocaesium and radiostrontium in sediments}

The concentrations of ${ }^{137} \mathrm{Cs},{ }^{134} \mathrm{Cs}$ and ${ }^{90} \mathrm{Sr}$ in the sediments were recorded. Over the whole period, the mean concentration of ${ }^{137} \mathrm{Cs}$ in sediments was $73.6 \mathrm{~Bq} \mathrm{~kg}^{-1}$ and in 2001-2010, it was $33.6 \mathrm{~Bq} \mathrm{~kg}^{-1}$. For the whole of the Czech Republic, the mean ${ }^{137} \mathrm{Cs}$ concentration in the period 2001-2010 was $12.9 \mathrm{~Bq} \mathrm{~kg}^{-1}$ (TGM WRI 2011), which indicates that the sediments in Orlík Reservoir and its tributaries were highly contaminated with ${ }^{137} \mathrm{Cs}$ compared with the rest of the Czech Republic. Mean concentration of ${ }^{90} \mathrm{Sr}$ in the period (1993-2010) of $1.8 \mathrm{~Bq} \mathrm{~kg}^{-1}$ was substantially below that of ${ }^{137} \mathrm{Cs}$.

The activities of these radionuclides are decreasing in time (Fig. 4). The rates of decline are similar for reference sampling sites and affected river sites and therefore the trends in the decline were evaluated for average annual

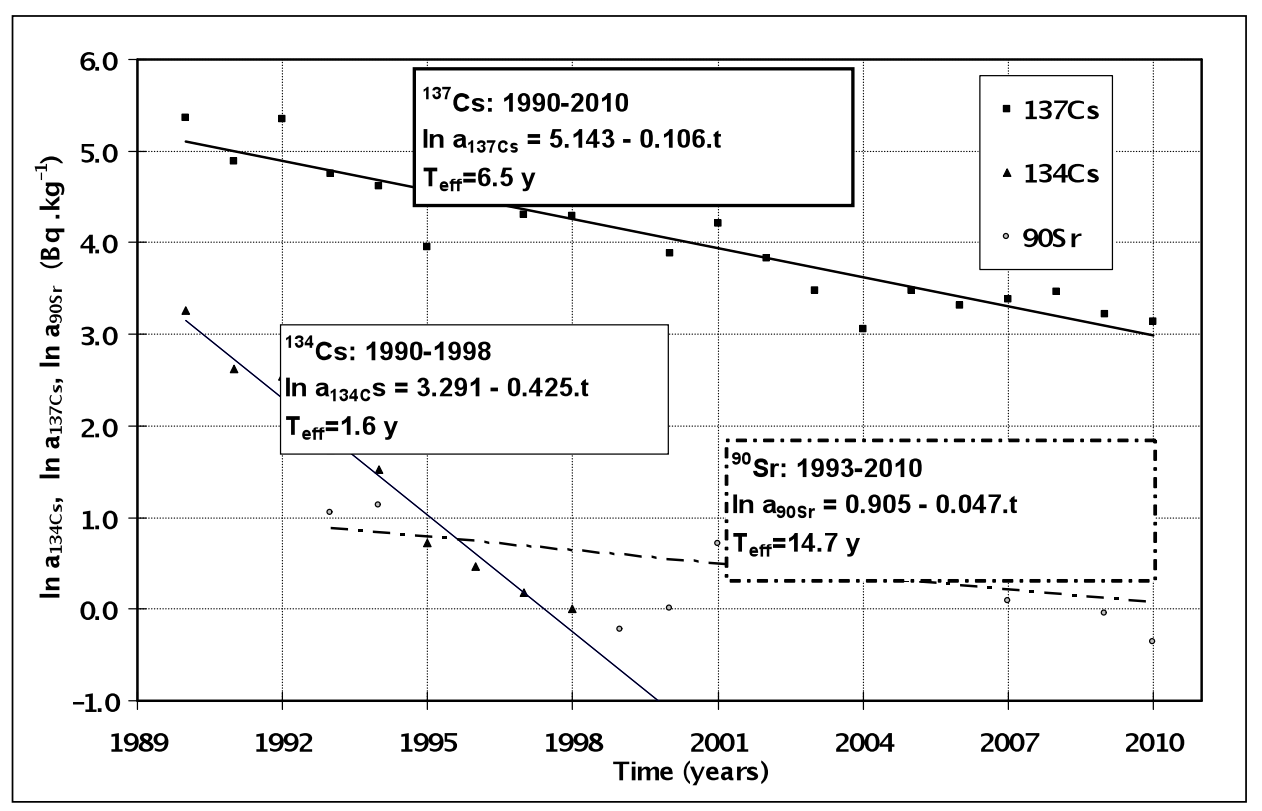

Fig. 4 Temporal changes of annual average concentrations of ${ }^{134} \mathrm{Cs}\left(\mathrm{a}_{134 \mathrm{Cs}}\right),{ }^{137} \mathrm{Cs}\left(\mathrm{a}_{137 \mathrm{Cs}}\right)$ and ${ }^{90} \mathrm{Sr}\left(\mathrm{a}_{90 \mathrm{Sr}}\right)$ in bottom sediments (dry matter) in Orlík Reservoir and its main tributaries in the periods $1990-1998\left({ }^{134} \mathrm{Cs}\right), 1990-2010\left({ }^{137} \mathrm{Cs}\right)$ and $1993-2010\left({ }^{90} \mathrm{Sr}\right)$. 


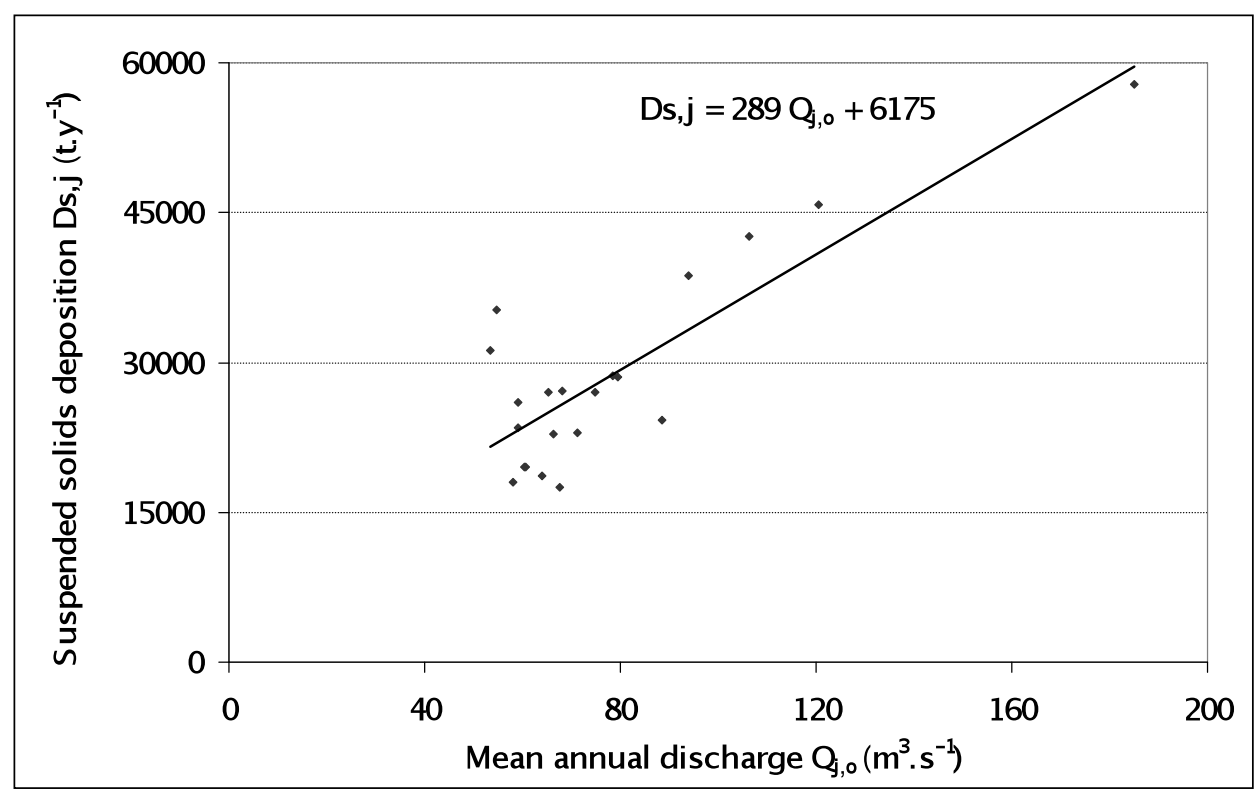

Fig. 5 Dependence of the suspended solids deposition in Orlík Reservoir on the annual mean flow.

activities for all sites. The assessment of ${ }^{134} \mathrm{Cs}$ was stopped in 1998 because in that year the values were below the MDA. The effective ecological half-life was 1.6 y for ${ }^{134} \mathrm{Cs}$ (for the period 1990-1998) and estimated ecological halflife was 7.8 y. For ${ }^{137} \mathrm{Cs}$, the effective half-life was $6.5 \mathrm{y}$ for the period 1990-2010. The estimated ecological half-life was $8.4 \mathrm{y}$. For ${ }^{90} \mathrm{Sr}$, the effective ecological half-life was 26.2 y for the period 1993-2010.

The results of the analysis of sediments showed that the residual contamination from the tests of nuclear weapons in the atmosphere and the Chernobyl accident in the last century is greater than that originating from the waste water from the Temelín power plant. Apart from ${ }^{134} \mathrm{Cs}$,
${ }^{90} \mathrm{Sr}$ and ${ }^{137} \mathrm{Cs}$, the results of the monitoring did not indicate that the sediments were contaminated with any other activation and fission products detectable using gamma-spectrometric analysis or ${ }^{90} \mathrm{Sr}$ determination.

\section{Depositions in Orlík Reservoir}

Data on river flows and concentrations of suspended solids, ${ }^{90} \mathrm{Sr}$ and ${ }^{137} \mathrm{Cs}$ were used to assess possible effects of the reservoir on the substances monitored.

Annual mean concentrations of suspended solids in samples from Orlík Reservoir and its tributaries were used together with annual mean flows for determining

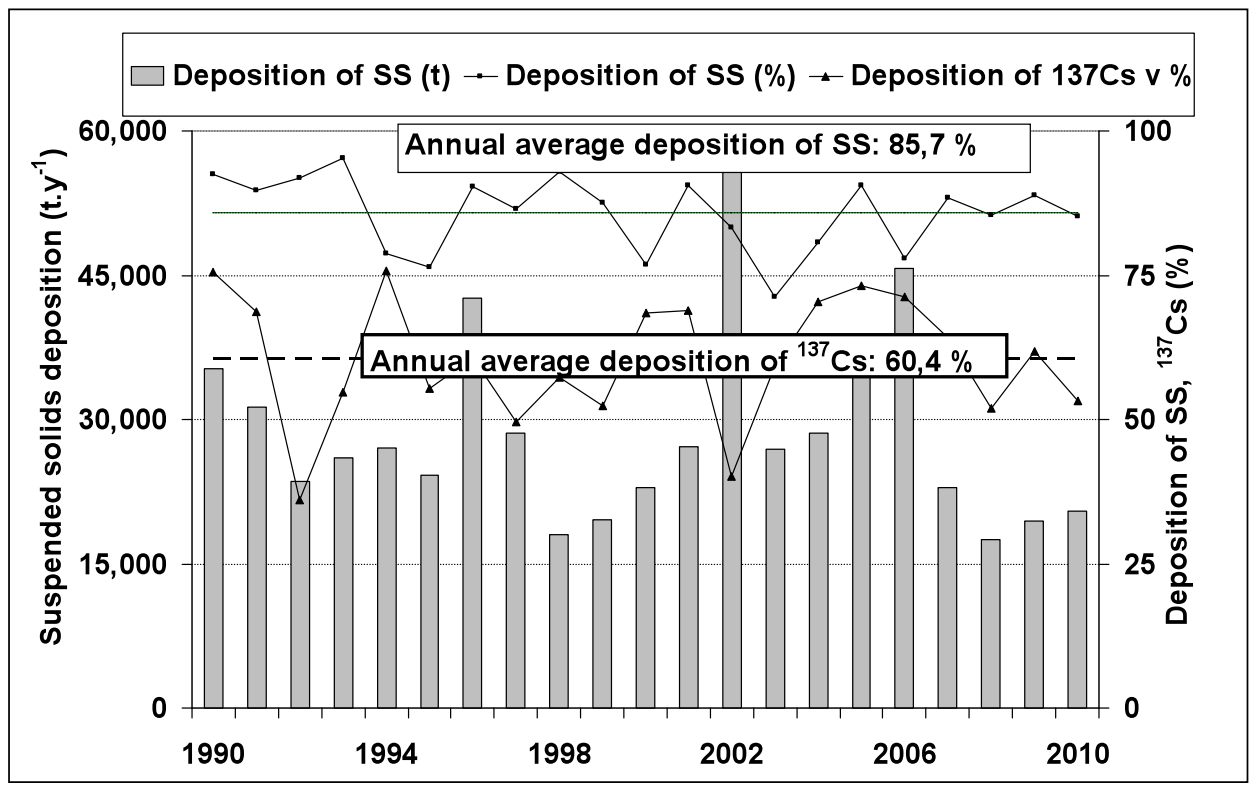

Fig. 6 Annual deposition of suspended solids (SS) and ${ }^{137} \mathrm{Cs}$ (deposited SS expressed in tons and percentages and deposited ${ }^{137} \mathrm{Cs}$ expressed in percentages in the period 1990-2010). 


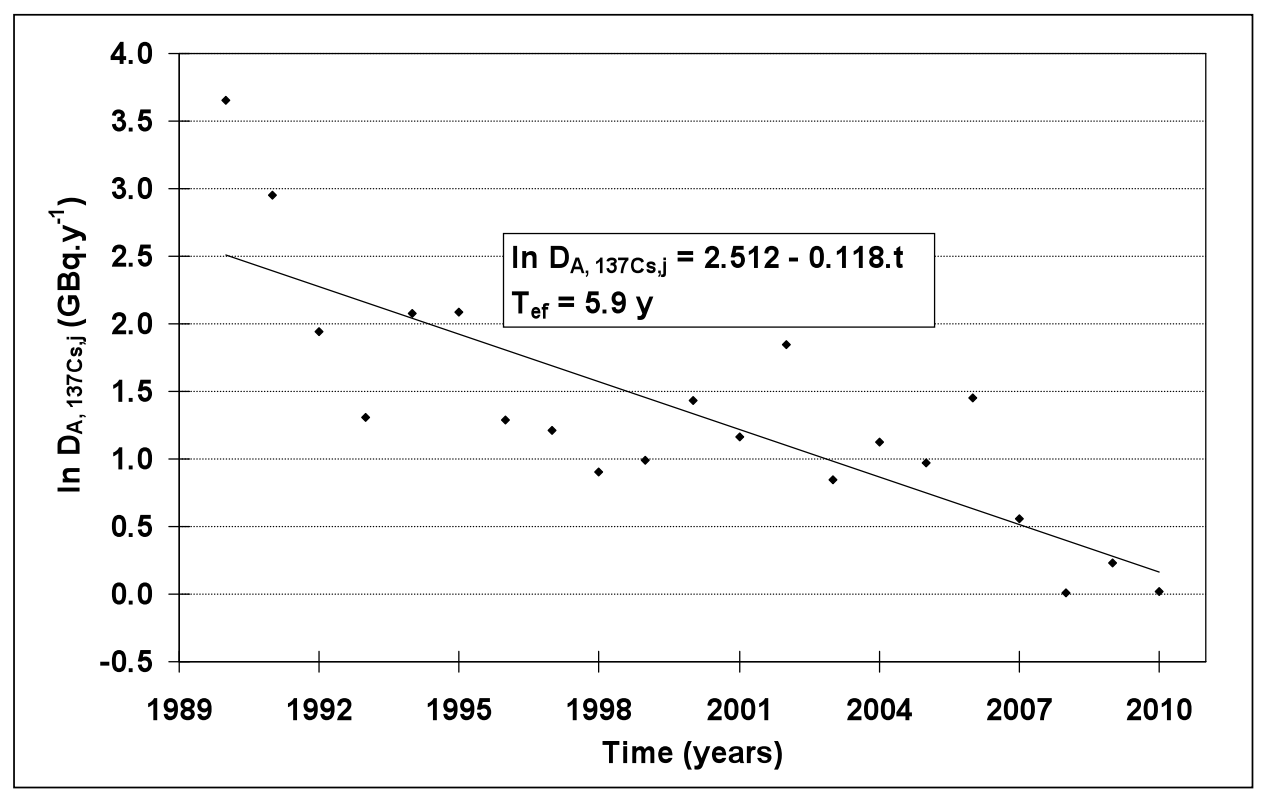

Fig. 7 Decrease in ${ }^{137}$ Cs deposition in Orlík Reservoir during 1990-2010.

the relationship between the deposition of suspended solids in Orlík Reservoir and annual mean flow (Fig. 5). Subsequently, this revealed that the annual deposition of suspended solids ranged between 71-95\% (with an average value of $85.7 \%$ ) of the inflow of suspended solids. In terms of mass, the annual mean deposition is 28,800 tons. The deposition of suspended matter in Orlík Reservoir expressed in percentages did not show any time dependence.

The annual deposition of ${ }^{137} \mathrm{Cs}$ was between $36 \%$ and $76 \%\left(1.0-19.2 \mathrm{GBq} \mathrm{r}^{-1}\right)$ and averaged $60.4 \%$. The annual deposition of suspended solids (SS) and ${ }^{137} \mathrm{Cs}$ is presented in Fig. 6. The annual deposition of ${ }^{137} \mathrm{Cs}$ decreased over time (Fig. 7) to a half-life of 5.9 years in the period 1990-2010. The temporal trend in the decrease is similar to that recorded in ${ }^{137} \mathrm{Cs}$ activity in water and bottom sediments in the study area. The mean percentage ${ }^{137} \mathrm{Cs}$ deposition was lower than that of suspended solids. This indicates that a part of the ${ }^{137} \mathrm{Cs}$ is dissolved in water and the deposited component is associated with solid particles. This assumption accords with the high distribution coefficients for ${ }^{137} \mathrm{Cs}(\mathrm{Kd})$ reported for Lake Constance and the river Rhine, which are in the range $4.6 \cdot 10^{4}-2.7 \cdot 10^{6} 1 \mathrm{~kg}^{-1}$ (Smith and Beresford 2005). The decrease in the deposition of ${ }^{137} \mathrm{Cs}$ in the Orlík Reservoir with an effective ecological half-life of 5.9 years accords with its half-life of 6.5 years based on the decrease in annual mean activity of ${ }^{137} \mathrm{Cs}$ in bottom sediments sampled from the reservoir and its tributaries during the period 1990-2010.

The analysis of ${ }^{90} \mathrm{Sr}$ concentrations showed that the outflow from the reservoir exceeds that of the inflow from the tributaries and the inter-basin area. The percentage outflow of ${ }^{90} \mathrm{Sr}$ was in the range $-37.8 \%$ to $72.1 \%$, with an average value of $19.6 \%$. The outflow of ${ }^{90} \mathrm{Sr}$ from the reservoir corresponds with the higher mobility and lower values of its Kd (750-1800 $\left.1 \mathrm{~kg}^{-1}\right)$ recorded for the area surrounding the Chernobyl Nuclear Power Plant (Smith and Beresford 2005).

Similar accumulations of ${ }^{137} \mathrm{Cs}$ are reported for the cascade of reservoirs constructed on the Dnepr River (Internet) and Lago di Lugano and Lago di Maggiore in Switzerland and Italy. The concentrations of ${ }^{137} \mathrm{Cs}$ in the upper lake (Lago di Lugano) exceed those in the lower lake (Lago di Maggiore) by one or two orders of magnitude (Putyrskaya et al. 2009). Accumulation of ${ }^{90} \mathrm{Sr}$ in reservoirs was not substantiated (IAEA 2005). During some periods, the ${ }^{90} \mathrm{Sr}$ concentrations in reservoirs can even remobilize and discharge from a reservoir, which is supported by the results for Orlík Reservoir, for which the mean ratio between the inflow and outflow of ${ }^{90} \mathrm{Sr}$ was 0.90 .

Outflows of ${ }^{137} \mathrm{Cs}$ and ${ }^{90} \mathrm{Sr}$ were assessed in relation to their concentrations in individual basins after the Chernobyl accident and tests of nuclear weapons in the atmosphere. During the period 1990-2010, the annual outflow of ${ }^{137} \mathrm{Cs}$ from individual basins did not exceed $0.01 \%$ of the total activity accumulated in the basin. At the end of this period, the annual outflows in the tributaries of Orlík Reservoir and of the outflow from the reservoir were in the range $0.002 \%$ to $0.005 \%$. Similarly, Erlinger et al. (2009) report that in 2005 the outflows from small basins in the Austrian Alps ranged between $0.0008 \%$ and $0.0031 \%$ with an average of $0.002 \%$. For the whole basin of the Vltava, Lužnice and Otava Rivers upstream from the Vltava River at Solenice, the total outflow of ${ }^{137} \mathrm{Cs}$ in the period $1986-2010$ was $0.5 \%$ of the ${ }^{137} \mathrm{Cs}$ activity accumulated in the basin, which confirms that the outflow of ${ }^{137} \mathrm{Cs}$ contributes little to the total reduction in ${ }^{137} \mathrm{Cs}$ in this basin. 
The contribution of the outflow of ${ }^{90} \mathrm{Sr}$ to its total reduction in the basin exceeds that of ${ }^{137} \mathrm{Cs}$ by approximately one order of magnitude. During the period 1986-2010, the outflow of ${ }^{90} \mathrm{Sr}$ represented 3.3\% of that present in the basin of the Vltava River at Solenice. This is similar to the results reported by Saxén and Ilus (2001), who conclude that the contribution of the outflow of ${ }^{90} \mathrm{Sr}$ exceeds that for ${ }^{137} \mathrm{Cs}$ because immobilization of ${ }^{90} \mathrm{Sr}$ in sediments is much less than the fixation of ${ }^{137} \mathrm{Cs}$.

\section{Bioaccumulation}

The monitoring of aquatic plants and fish focused on determining the concentrations of ${ }^{137} \mathrm{Cs}$ and ${ }^{90} \mathrm{Sr}$. The concentrations of ${ }^{137} \mathrm{Cs}$ in fish (in terms of fresh weight) were assessed for the periods 1986-1990 and 1994-2010. Between the two periods, the ${ }^{137} \mathrm{Cs}$ concentrations decreased from $2.0-51.4 \mathrm{~Bq} \mathrm{~kg}^{-1}$ (1986-1990) to $0.08-2.00 \mathrm{~Bq} \mathrm{~kg}^{-1}$ (1994-2010). As there was less data available on the concentrations of ${ }^{90} \mathrm{Sr}$ in fish the value was assessed for the whole period 1990-2010, for which the mean concentration was $0.8 \mathrm{~Bq} \mathrm{~kg}^{-1}$. The results of the monitoring and assessment of the ${ }^{137} \mathrm{Cs}$ and ${ }^{90} \mathrm{Sr}$ concentrations in fish are presented in Fig. 8. The concentrations in the Czech Republic are substantially below those in areas affected by the first radioactive cloud. In the most affected areas in the vicinity of Chernobyl, these activities shortly after the accident were at levels of hundreds of $\mathrm{kBq} \mathrm{kg}^{-1}$ and in the early nineties were still at levels of tens of $\mathrm{kBq} \mathrm{kg}^{-1}$. Activities of several $\mathrm{Bq} \mathrm{kg}^{-1}$ in this period were also reported from Switzerland, England and Germany (Smith et al. 2000b).

Relatively rare information on ${ }^{90} \mathrm{Sr}$ concentrations in fish include those of Outola et al. (2009), who report that in the period 1978-1997 the concentrations in the river species they analyzed were in the range of $10-17 \mathrm{~Bq} \mathrm{~kg}^{-1}$, which exceeds the ${ }^{90} \mathrm{Sr}$ concentrations in fish from Orlík Reservoir by approximately one order of magnitude. The concentration levels of ${ }^{90} \mathrm{Sr}$ were however smaller by several orders of magnitude compared to those for ${ }^{137} \mathrm{Cs}$. Most of the ${ }^{90} \mathrm{Sr}$ is in bones and thus it is less dangerous than ${ }^{137} \mathrm{Cs}$ in terms of radioactive doses originating from the food chain (Outola et al. 2009).

In accord with the results for surface water, the concentrations of ${ }^{137} \mathrm{Cs}$ and ${ }^{90} \mathrm{Sr}$ in fish also decreased over time. Evaluated effective ecological half-life $\left(T_{\text {eff }}\right)$ of ${ }^{137} \mathrm{Cs}$ was $1.0 \mathrm{y}$ for the period $1986-1990$ and $4.5 \mathrm{y}$ for the period 1994-2010 and that of the ecological half-lives $\left(T_{\text {ecol }}\right)$ $1.1 \mathrm{y}$ and $5.4 \mathrm{y}$, respectively. Similar results are reported by Franić and Marović (2007) for Croatia over the period 1987-1992, while this decrease is greater than that reported by Smith et al. (2000b) for the same period. The reported half-lives are in the range 2 to 3 years. In accord with the results for the Czech Republic, the literature indicates that the decrease in the following period was significantly less when expressed in terms of physical halflife. The effective ecological half-life in the Finland lakes is between 3 and 6 years (Outola et al. 2009). Franić and Marović (2007) report 5 years for the period 1993-2005. The ${ }^{137} \mathrm{Cs}$ half-life for fish is similar to that for water. The decrease continued also during the operation of the Temelín power plant.

The half-life reported for ${ }^{90} \mathrm{Sr}$ is substantially longer. Evaluated effective ecological half-life $\left(T_{e f f}\right)$ for ${ }^{90} \mathrm{Sr}$ was 6.4 y for the period 1990-2010 and ecological half-life $\left(T_{\text {ecol }}\right) 8.2 \mathrm{y}$. The effective ecological half-lives for several species of fish in Finish lakes range between 7 and 30 years (Outola et al. 2009).

The results of monitoring the ${ }^{137} \mathrm{Cs}$ and ${ }^{90} \mathrm{Sr}$ in surface water and fish (fresh weight) were used to determine

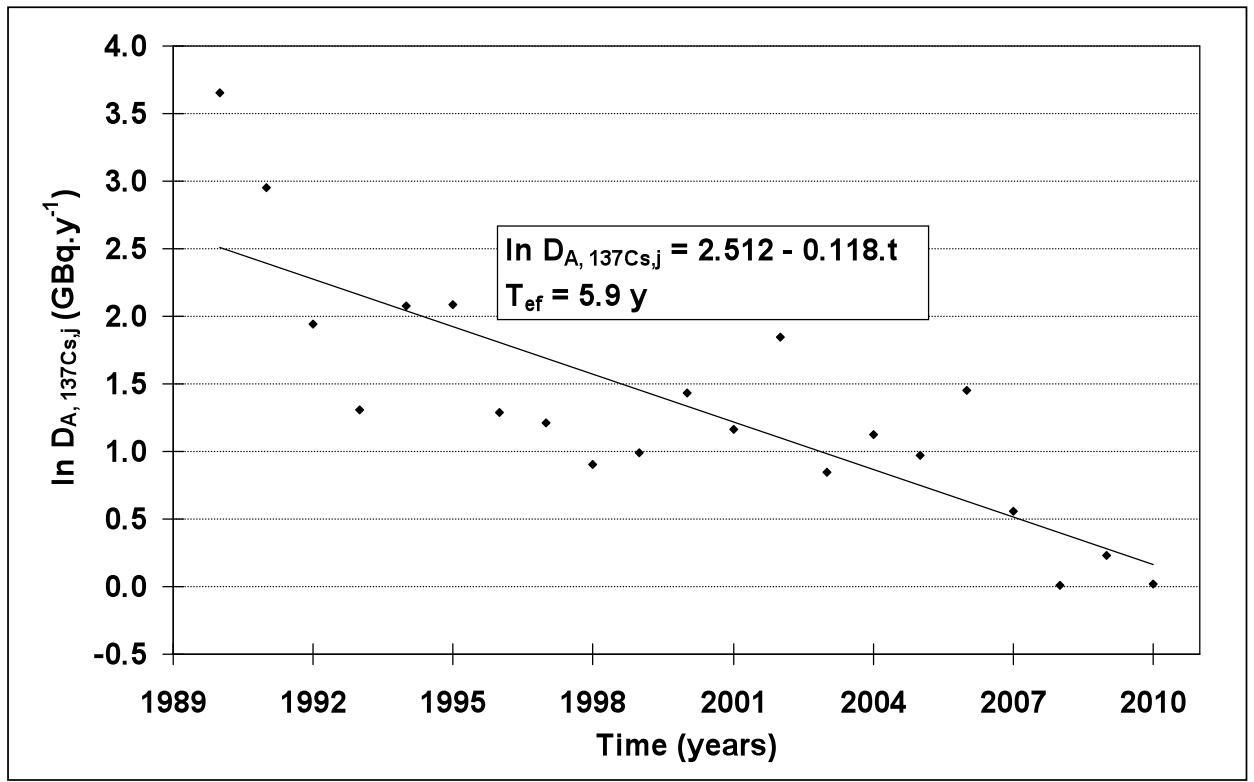

Fig. 8 Temporal changes in ${ }^{137} \mathrm{Cs}$ and ${ }^{90} \mathrm{Sr}$ concentrations ( $(137 \mathrm{Cs}$, a90Sr) in fish (wet weight) in Orlík Reservoir in the periods 1986-1990, 1994-2010 (a137Cs) and 1990-2010 (a90Sr). 
the concentration factors $C F_{137 \mathrm{Cs}}$ and $C F_{90 \mathrm{Sr}}$ Outola et al. (2009) conclude that the concentration factor can be calculated when conditions have stabilized, which occurs 8 to 10 years after an accident. For Orlík Reservoir, the $C_{137 \mathrm{Cs}}$ values calculated for the period 1986-1990 did not differ significantly from those for the period after 1994 and therefore the mean $\mathrm{CF}_{137 \mathrm{Cs}}$ was calculated using all the values. The resulting value was $309 \mathrm{l} \mathrm{kg}^{-1}$. The mean $C F_{137 \mathrm{Cs}}$ value specified in IAEA (2010) is $3.0 \cdot 10^{3} \mathrm{l} \mathrm{kg}^{-1}$ and the range $4.5 \cdot 10^{1}-2.4 \cdot 10^{4} \mathrm{l} \mathrm{kg}^{-1}$, whereas the mean ${ }^{137} \mathrm{Cs}$ for fish species in Orlík Reservoir is smaller by one order of magnitude. All of the values calculated were, however, in the range reported by IAEA (2010).

For ${ }^{90} \mathrm{Sr}$, the mean concentration factor $\left(\mathrm{CF}_{90 \mathrm{Sr}}\right)$ was $1241 \mathrm{~kg}^{-1}$, which is similar to the mean of $1.9 \cdot 10^{2} 1 \mathrm{~kg}^{-1}$ (range of $2.2 \cdot 10^{1}-7.1 \cdot 10^{2} \mathrm{l} \mathrm{kg}^{-1}$ ) reported in IAEA (2010). Similar results are reported by Smith and Beresford (2005) for lakes in the vicinity of Chernobyl (46-452) while Outola et al. (2009) report $550-13001 \mathrm{~kg}^{-1}$ for lakes in Finland.

Concentrations of ${ }^{137} \mathrm{Cs}$ were monitored in several species of aquatic plants (dried material). The results substantiated the assumption that the highest concentrations of ${ }^{137} \mathrm{Cs}$ occur in aquatic mosses $\left(21.8 \mathrm{~Bq} \mathrm{~kg}^{-1}\right.$ in 1996) and algae (17.9 $\mathrm{Bq} \mathrm{kg}^{-1}$ in 1996). A comparison of the results for sites unaffected and affected by the outflow from the Temelín power plant was complicated because different species of plants grew at the individual sites with exception of reeds. Since 2006, the monitoring was confined to reeds, which were also used for the assessment. The results indicate that the concentrations of ${ }^{137} \mathrm{Cs}$ in reeds decreased with the effective ecological half-life 13.5 years. The decrease occurred at both the unaffected and affected river sites and continued after the Temelín power plant became operational. The ${ }^{90} \mathrm{Sr}$ concentration in reeds ranged between 0.5 and $6.1 \mathrm{~Bq} \mathrm{~kg}^{-1}$ (in dry matter) and this concentration decreased with an effective ecological half-life of 6.9 years.

A summary of the effective ecological half-lives and ecological half-lives of ${ }^{134} \mathrm{Cs},{ }^{137} \mathrm{Cs}$, and ${ }^{90} \mathrm{Sr}$ and the con- centration factors for individual components of the hydrosphere is presented in Table 3. The periods of time over which the assessments were made are given in detail in the above text.

\section{Conclusions}

The results of the systematic monitoring of possible effects of the Temelín power plant on the hydrosphere show that the waste water discharges meet the limits specified in the permit on water management (Decision of Regional Authority - Permit on Water management 2007) and the Resolution of the Czech Government No. 229/2007 Coll. Concentrations of anthropogenic radionuclides in the hydrosphere downstream from the waste water outflow from the Temelín power plant are mainly due to the residual contamination from global fallout and the Chernobyl accident. Apart from tritium, the effects of the Temelín power plant on the concentration of activation and fission products in the hydrosphere were negligible.

For two periods of time, 1990-1994 and 1995-2010, the concentrations of ${ }^{137} \mathrm{Cs}$ in surface water and fish, and for one period, 1990-2010, in sediments and in 1996-2010, in aquatic plants. Its effective ecological halflife in water in individual tributaries and the outflow from Orlík Reservoir were in the range 1.1-2.2 years for 1990-1994 and 6.2-10.9 years for 1995-2010. These results indicate that in the first period, which is shortly after the accident at Chernobyl, the concentrations of ${ }^{137} \mathrm{Cs}$ were rapidly decreasing and continued to decline but at a slower rate in the second period (after 1995). Its effective ecological half-life in fish was $1.0 \mathrm{y}$ for the period 1986-1990 and 4.5 years for the period 1994-2010. Concentrations of ${ }^{137} \mathrm{Cs}$ in water and fish decreased at approximately the same rate. Temporal changes in the concentrations of ${ }^{134} \mathrm{Cs}$ and ${ }^{137} \mathrm{Cs}$ in sediments were recorded for the periods 1990-1998 and 1990-2010. The monitoring of ${ }^{134}$ Cs stopped in 1998 because in that year all the

Table 3 Summary of the effective ecological and ecological half-lives of ${ }^{134} \mathrm{Cs},{ }^{137} \mathrm{Cs}$ and ${ }^{90} \mathrm{Sr}$, and concentrations in different components of the hydrosphere (The time periods over which these were assessed are given in text).

\begin{tabular}{|c|c|c|c|c|c|c|c|c|c|c|c|c|c|c|}
\hline & \multicolumn{4}{|c|}{${ }^{134} \mathrm{Cs}$} & \multicolumn{5}{|c|}{${ }^{137} \mathrm{Cs}$} & \multicolumn{5}{|c|}{${ }^{90} \mathrm{Sr}$} \\
\hline & \multicolumn{2}{|c|}{$\begin{array}{l}T_{\text {eff }} \\
(\mathbf{y})\end{array}$} & \multicolumn{2}{|c|}{$\begin{array}{c}T_{\text {ecol }} \\
\text { (y) }\end{array}$} & \multicolumn{2}{|c|}{$\begin{array}{l}T_{\text {eff }} \\
(\mathbf{y})\end{array}$} & \multicolumn{2}{|c|}{$\begin{array}{c}T_{\text {ecol }} \\
\text { (y) }\end{array}$} & \multirow{3}{*}{$\begin{array}{c}\text { CF } \\
1 / \mathbf{k g} \\
-\end{array}$} & \multicolumn{2}{|c|}{$\begin{array}{l}T_{\text {eff }} \\
(\mathbf{y})\end{array}$} & \multicolumn{2}{|c|}{$\begin{array}{c}T_{\text {ecol }} \\
\text { (y) }\end{array}$} & \multirow{3}{*}{$\begin{array}{c}\text { CF } \\
1 / \mathbf{k g} \\
-\end{array}$} \\
\hline \multirow{2}{*}{ Water } & \multirow{2}{*}{\multicolumn{4}{|c|}{ - }} & 1.7 & \pm 2.1 & 1.8 & \pm 2.4 & & 9.8 & \pm 7.6 & 15.0 & \pm 12.0 & \\
\hline & & & & & 7.5 & \pm 5.1 & 10.3 & \pm 9.8 & & & & & & \\
\hline Sediment & 1.6 & \pm 0.3 & 7.8 & \pm 6.0 & 6.5 & \pm 1.4 & 8.4 & \pm 2.3 & - & 15.0 & \pm 21.0 & 30.0 & \pm 87.0 & \\
\hline \multirow{2}{*}{ Fish } & \multirow{2}{*}{\multicolumn{4}{|c|}{ - }} & 1.0 & \pm 0.2 & 1.1 & \pm 0.2 & 310 & 6.4 & \pm 4.0 & 8.2 & \pm 6.6 & 124 \\
\hline & & & & & 4.5 & \pm 1.5 & 5.3 & \pm 2.1 & \pm 190 & & & & & \pm 80 \\
\hline Flora & \multirow{2}{*}{\multicolumn{4}{|c|}{ - }} & 14 & \pm 13 & 25 & \pm 43.0 & 64 & 6.9 & \pm 2.8 & 9.1 & \pm 4.9 & 20 \\
\hline (Reeds) & & & & & & & & & \pm 30 & & & & & \pm 9 \\
\hline
\end{tabular}

European Journal of Environmental Sciences, Vol. 3, №. 1 
values were below the MDA. The effective half-life was $1.6 \mathrm{y}$ for ${ }^{134} \mathrm{Cs}$ in the period $1990-1998$ and $6.5 \mathrm{y}$ for ${ }^{137} \mathrm{Cs}$ in $1990-2010$. The values for the concentration of ${ }^{137} \mathrm{Cs}$ in reeds revealed that it was decreasing with an effective ecological half-life of 13.5 years. This decrease was recorded in both unaffected and affected rivers and continued even after the Temelín power plant became operational.

Temporal changes in the concentrations of ${ }^{90} \mathrm{Sr}$ in water collected from Orlík Reservoir and its tributaries were recorded for the period 1993-2010. The effective ecological half-life in water in individual tributaries and the outflow from Orlík Reservoir were in the range 7.9-12.8 y. Temporal changes in the concentrations of ${ }^{90} \mathrm{Sr}$ in sediments were recorded for the period 1993-2010. The effective ecological half-life was $26.2 \mathrm{y}$. The concentration of ${ }^{90} \mathrm{Sr}$ in reeds decreased over this period and its effective ecological half-life was 6.9 years.

The differences in the effective half-lives recorded at the different sites are due to differences in the conditions at these sites. They can differ from each other, for example, in flow velocity, concentration of suspended solids or quality of the sediments.

Data on river flow and concentrations of suspended solids were used to assess possible effects of the reservoir on the monitoring of ${ }^{90} \mathrm{Sr}$ and ${ }^{137} \mathrm{Cs}$. The annual deposition of suspended solids ranged between 71-95\% (with an average value of $85.7 \%$ ) of that in the inflow. The annual deposition of ${ }^{137} \mathrm{Cs}$ was between $36 \%$ and $76 \%$ with an average value of $60.4 \%$. The annual deposition of ${ }^{137} \mathrm{Cs}$ decreased over time and its half-life in the period 1990-2010 was 5.9 years. The analysis of the concentrations of ${ }^{90} \mathrm{Sr}$ revealed that there was more in the outflow from the reservoir than in the inflow from the tributaries and inter-basin area. The percentage outflow of ${ }^{90} \mathrm{Sr}$ was in the range $-37 \%$ to $72 \%$ with an average of $20 \%$.

During the period 1990-2010, the concentration factor for ${ }^{137} \mathrm{Cs}$ in fish was on average $3091 \mathrm{k}^{-1} \mathrm{~g}$.

The concentrations of ${ }^{137} \mathrm{Cs}$ and ${ }^{90} \mathrm{Sr}$ in the surface water, river bottom sediments, fish and aquatic flora collected from the vicinity of the Temelín power plant decreased over the period of this study, even in the samples collected downstream from the waste water outflow from the Temelín power plant.

\section{Acknowledgements}

This paper was prepared from the results of project MZP 0002071101, which was sponsored by the Ministry of the Environment of the Czech Republic.

\section{REFERENCES}

ČSN EN 25667-1 Water Quality (1995) Sampling. Part 1: Guidance on the design of sampling programs (ISO 5667-1:1980). Czech Institute for Standardization, Prague, (in Czech).
ČSN EN 25667-2 Water Quality (1995) Sampling. Part 2: Guidance on sampling techniques (ISO 5667-2:1991). Czech Institute for Standardization, Prague, (in Czech).

ČSN EN ISO 5667-3 Water Quality (2004) Sampling. Part 3: Guidance on preservation and handling of water samples (ISO 5667-3:2003). Czech Institute for Standardization, Prague, (in Czech).

ČSN EN ISO 5667-6 Water Quality (1994) Sampling. Part 6: Guidance on sampling of rivers and streams (ISO 5667-6:1990). Czech Institute for Standardization, Prague, (in Czech).

ČSN EN ISO/IEC 17025 (2001) General requirements for the competence of testing and calibration laboratories, Czech Institute for Standardization, (in Czech).

ČSN EN ISO/IEC 17025 (2005) General requirements for the competence of testing and calibration laboratories, Czech Institute for Standardization, (in Czech).

ČSN ISO 10703 (75 7630) (1999) Water Quality - Determination of the activity concentration of radionuclides - Method by high resolution gamma-ray. Czech Institute for Standardization, Prague, (in Czech).

ČSN ISO 10703 (2008) Water Quality - Determination of the activity concentration of radionuclides - Method by high resolution gamma-ray. Czech Institute for Standardization, Prague, (in Czech).

Erlinger Ch, Ettner H, Hubmer A, Hofmann W, Steinhäusler F (2009) Determination of ${ }^{137} \mathrm{Cs}$ in the water system of a pre-Alpine lake. J Environ Radioactiv 100: 354-360.

Franić Z, Marović G (2007) Long-term investigations of radiocaesium activity concentrations in carp in North Croatia after the Chernobyl accident. J Environ Radioactiv 94: 75-85.

Hanslík E (1993) Determination of strontium 90. In: Čapková A. Guidelines for determination of water pollution parameters, Ministry of the Environment, Prague, (in Czech).

Hanslík E (1995) Impact of Temelín Nuclear Power Plant on hydrosphere and other components of environment, Final research report, T. G. Masaryk Water Research Institute, Prague, (in Czech).

Hanslík E (1998) Impact of nuclear devices on environment, Final research report, T. G. Masaryk Water Research Institute, Prague, (in Czech).

Hanslík E (2000) Assessment of surface and groundwater quality in connection with construction and operation Temelín Nuclear Power Plant on surrounding environment, Research report, T. G. Masaryk Water Research Institute, Prague, (in Czech).

Hanslík E (2001) Assessment of surface and groundwater quality in connection with onstruction and operation Temelín Nuclear Power Plant on surrounding environment, Research report, T. G. Masaryk Water Research Institute, Prague, (in Czech).

Hanslík E (2002) Assessment of surface and groundwater quality in connection with construction and operation Temelín $\mathrm{Nu}$ clear Power Plant on surrounding environment, Research report, T. G. Masaryk Water Research Institute, Prague, (in Czech).

Hanslík E (2003) Assessment of surface and groundwater quality in connection with construction and operation of Temelín Nuclear Power Plant on surrounding environment, Research report, T. G. Masaryk Water Research Institute, Prague, (in Czech).

Hanslík E (2004) Assessment of surface and groundwater quality in connection with construction and operation of Temelín Nuclear Power Plant on surrounding environment, Research report, T. G. Masaryk Water Research Institute, Prague, (in Czech).

Hanslík E (2005) Assessment of surface and groundwater quality in connection with construction and operation of Temelín Nuclear Power Plant on surrounding environment, Research Water Research Institute, Prague, (in Czech). 
Hanslík E (2006) Assessment of surface and groundwater quality in connection with construction and operation of Temelín Nuclear Power Plant on surrounding environment, Research report, T. G. Masaryk Water Research Institute, Prague, (in Czech).

Hanslík E (2007) Assessment of surface and groundwater quality in connection with construction and operation of Temelín Nuclear Power Plant on surrounding environment, Research report, T. G. Masaryk Water Research Institute, Prague, (in Czech).

Hanslík E (2008) Assessment of surface and groundwater quality in connection with construction and operation of Temelín Nuclear Power Plant on surrounding environment, Research report, T. G. Masaryk Water Research Institute, Prague, (in Czech).

Hanslík E (2009) Assessment of surface and groundwater quality in connection with construction and operation of Temelín Nuclear Power Plant on surrounding environment, Research report, T. G. Masaryk Water Research Institute, Prague, (in Czech).

Hanslík E (2010) Assessment of surface and groundwater quality in connection with construction and operation of Temelín Nuclear Power Plant on surrounding environment, Research report, T. G. Masaryk Water Research Institute, Prague, (in Czech).

Hanslík E (2011) Assessment of surface and groundwater quality in connection with construction and operation of Temelín Nuclear Power Plant on surrounding environment, Research report, T. G. Masaryk Water Research Institute, Prague, (in Czech).

IAEA (1996) Evaluation of water resources monitoring, Report on assessment of analytical methods for radioactivity monitoring, RU-6172 (CZR/8/002), Vienna.

IAEA (2005) Environmental Consequences of the Chernobyl Accidentand their Remediation:Twenty Years of ExperienceReport of the UN Chernobyl Forum Expert Group "Environment” (EGE). http://www-ns.iaea.org/downloads/rw/meetings/environ -consequences-report-wm-08.05.pdf, Accessed 29 April 2010.
IAEA (2010) Handbook of parameter values for the prediction of radionuclide transfer in terrestrial and freshwater environments, Technical reports series No. 472, IAEA, Vienna.

Ivanovová D, Hanslík E (2010) Temporal and spatial changes in tritium concentration in the Vltava River basin affected by the operation of Temelín Nuclear Power Plant. Acta Univ Carol Environ 1-2: 17-31.

Outola I, Saxén RL, Heinävaara (2009) Transfer of ${ }^{90} \mathrm{Sr}$ into fish in Finnish lakes. J Environ Radioactiv 100: 657-664.

Permit on Water Management (2007) No. 18378/20/2005 OZZL, České Budějovice, 22. 1. 2007 (in Czech).

Putyrskaya V, Klemt E, Röllin S (2009) Migration of ${ }^{137}$ Cs in tributaries, lake water and sediments of Lago Maggiore (Italy, Switzerland) - analysis and comparison with Lago di Lugano and other lakes. J Environ Radioactiv 100: 35-48.

Saxén R, Ilus, E (2001) Discharge of ${ }^{137} \mathrm{Cs}$ and ${ }^{90} \mathrm{Sr}$ by Finish rivers to the Baltic Sea in 1986-1996. J Environ Radioactiv 54: 275-291.

Smith JT, Clarke RT, Saxén R (2000a) Time-dependent behaviour of radiocaesium: A new method to compare the mobility of weapons test and Chernobyl derived fallout. J Environ Radioactiv 49: 65-83.

Smith JT, Kudelsky AV, Ryabov IN, Hadderingh RH (2000b) Radiocaesium concentration factors of Chernobyl-contaminated fish: study of the influence of potassium, and "blind" testing of a previously developed model. J Environ Radioactiv 48: 359-369.

Smith JT, Beresford NA (2005) Chernobyl - Catastrophe and Consequences, Praxis Publishing Ltd, Chichester, UK.

Resolution of the Czech Government No. 229/2007 Coll., Ministry of the Environment of the Czech Republic, (in Czech)

T. G. Masaryk Water Research Institute (2011). Non-published results, Prague.

Zibold G, Kaminski S, Klemt E, Smith JT (2001) Time-dependency of the ${ }^{137} \mathrm{Cs}$ activity concentration in fresh lakes, measurement and prediction, Radioprotection, Vol. 37, C1, 2002, Proceeding of the International Congress ECORAD 2001, Aix-en-Provence, France, pp. 75-80. 